\title{
Chapter 10 \\ Displacement and Resettlement: \\ Understanding the Role of Climate \\ Change in Contemporary Migration
}

\author{
Alison Heslin, Natalie Delia Deckard, Robert Oakes \\ and Arianna Montero-Colbert
}

\begin{abstract}
How do we understand displacement and resettlement in the context of climate change? This chapter outlines challenges and debates in the literature connecting climate change to the growing global flow of people. We begin with an outline of the literature on environmental migration, specifically the definitions, measurements, and forms of environmental migration. The discussion then moves to challenges in the reception of migrants, treating the current scholarship on migrant resettlement. We detail a selection of cases in which the environment plays a role in the displacement of a population, including sea level rise in Pacific Island States, cyclonic storms in Bangladesh, and desertification in West Africa, as well as the role of deforestation in South America's Southern Cone as a driver of both climate change and migration. We outline examples of each, highlighting the complex set of losses and damages incurred by populations in each case.
\end{abstract}

Keywords Migration - Internal displacement $\cdot$ Resettlement $\cdot$ Climate change Natural disasters $\cdot$ Environmental degradation $\cdot$ Loss and Damage $\cdot$ Refugee

\subsection{Introduction}

How do we understand displacement and resettlement in the era of climate change? Scholars, practitioners, and policy-makers have been grappling with ways to improve life outcomes for large numbers of refugees and migrants. In particular, the 21 st conference of the Parties to the United Nations Climate Convention (UNFCCC) in Paris created a taskforce to work out recommendations to "avert, minimize, and address

\footnotetext{
A. Heslin $(\varangle)$

International Institute of Applied Systems Analysis, Laxenburg, Austria

e-mail: heslin@iiasa.ac.at

N. Delia Deckard · A. Montero-Colbert

Davidson College, Davidson, USA

R. Oakes

United Nations University, Bonn, Germany

(C) The Author(s) 2019

R. Mechler et al. (eds.), Loss and Damage from Climate Change, Climate Risk

Management, Policy and Governance, https://doi.org/10.1007/978-3-319-72026-5_10
} 
displacement related to the adverse impacts of climate change" (UNFCCC 2017). In addressing the role of climate change in displacement, one must identify the ways that factors pertaining to environmental change generally drive migration, as this relationship will become all the more important and complex with climate change (IOM 2017b). This chapter addresses the ways that the natural environment relates to the global flow of people (Bettini and Andersson 2014; Bates 2002; Dun and Gemenne 2008). In addressing this relationship between the environment and displacement, we first outline the primary debates within the environmental displacement and migration literature, as well as challenges in the reception of migrants in host communities and nations. Using cases of climate-related displacement, we then highlight the complexity of the social effects of environmental factors and the process of migration.

\subsection{Defining and Measuring Migration}

The complexity of environmental migration begins with the process of setting concrete, agreed upon definitions, however, defining and subsequently measuring the process of environmental migration is not uniform throughout the literature (Dun and Gemenne 2008).

\subsubsection{Definitions}

To understand the various means by which one can define environmental migration, we may start by understanding the broader categories used to describe populations outside their habitual place of residence, including migrant, refugee, asylum seeker, and internally displaced person. In general, one may classify a person in these different categories based on the circumstances of their leaving their place of residence and the destination of their movement (outlined in Fig. 10.1). According to the International Organization for Migration, migrant is the most general term, encompassing any person who "has moved across an international border or within a State away from his/her habitual place of residence" (IOM 2018). By this definition, anyone who falls within our matrix outlined in Fig. 10.1 is a migrant, but depending on the circumstances of their movement, more precise labels and terminology can be used to describe them. For instance, if one flees across an international border due to a "well-founded fear of being persecuted for reasons of race, religion, nationality, membership of a particular social group or political opinion," they can be further classified as a refugee or asylum-seeker (UN 1951). In addition, one who is forced to flee their home, but has not crossed an international border is considered an internally displaced person (IDP) (IOM 2017c; UN 1998).

While the IOM definitions of refugees and IDPs are consistent with UN conventions, the definition of migrant used by the IOM differs from that of the UN, which uses a more narrow definition of migrant. According to the UN, a migrant is one 


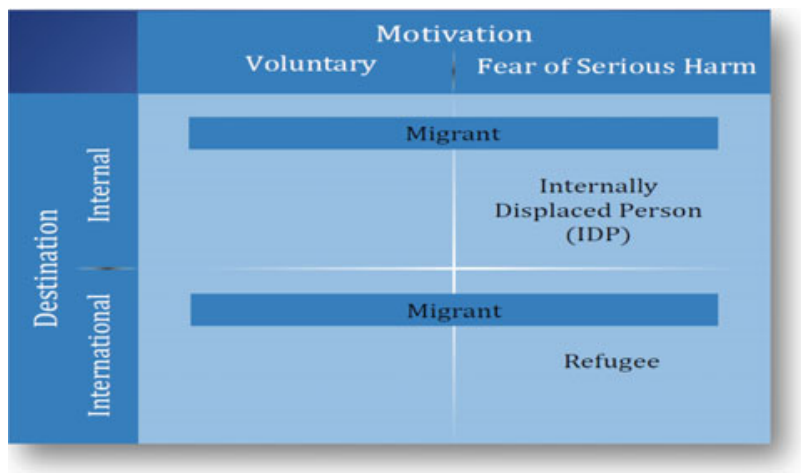

Fig. 10.1 IOM migration-related terminology by motivation and destination. Source IOM (2017c)

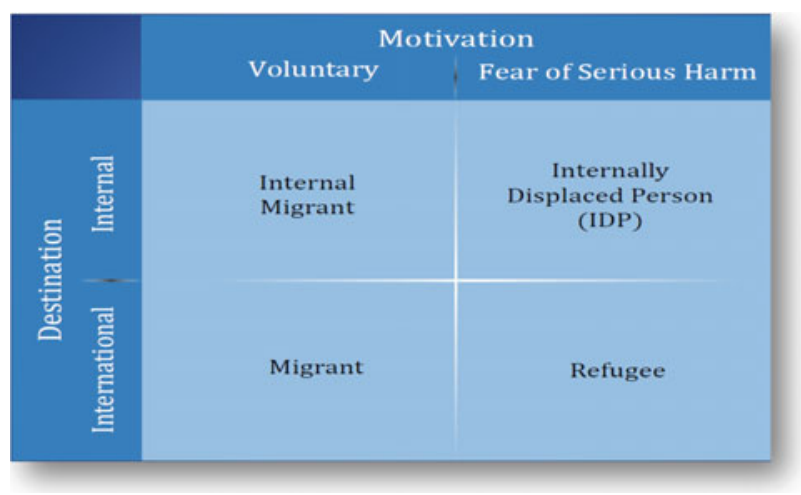

Fig. 10.2 UN migration-related terminology by motivation and destination. Sources UN (1951), UN (1990), UN (1998)

residing outside the country of which he/she is a national, not including those categorised as refugees or asylum seekers (UN 1990). By the UN definition, migrant would occupy only the bottom-left quadrant, shown in Fig. 10.2. This UN distinction is useful to differentiate the four categories into four separate, non-overlapping labels - internal migrant, internally displaced person, migrant, and refugee/asylum seeker-to be determined by two questions: Was the movement domestic or international? and was the movement voluntary or forced?

At its most simple, moving from migration broadly to environmental migration specifically entails maintaining the same categories, but restricting to cases in which the motivating factor for movement was environmentally-related, including those caused by climate change. The IOM does just this, maintaining the encompassing definition for migration, defining an environmental migrant as a person who 
for reasons of sudden or progressive changes in the environment that adversely affect their lives or living conditions, are obliged to have to leave their habitual homes, or choose to do so, either temporarily or permanently, and who move either within their territory or abroad (IOM 2017c).

Alternatively, using the more restricted definition of migrant from the UN (voluntary, international), an environmental migrant would be one who voluntarily resides outside his/her country for reasons of changes to the environment, suddenor gradually-onset. Internal environmental migrants voluntarily relocate domestically for reasons of environmental changes. An environmental refugee would be one who, due to environmental factors, is forced to flee home and cross international borders, whereas an environmental IDP is also forced to leave home but remains within the state of which he/she is a national. While these terms may seem well defined, the process of identifying populations that fall into each category is rife with complications, leading to scientific and policy debates on the specific criteria of the definitions. In determining the category into which a person falls, locating the person as within or without their national borders is the most straightforward, while determining whether or not that person moved voluntarily and whether or not that movement was motivated by environmental factors, is cause for much debate in the literature. The decision to leave a place of residence is multifaceted, comprised of both push and pull factors (Bronen et al. 2009; Obokata et al. 2014; Renaud et al. 2007; Warner et al. 2010). In the case of slow onset land degradation, with decreasing crop yields, for example, one could argue that a resident left willingly or was forced to leave, as well as arguing that said resident left for new economic opportunities in a nearby city or left for environmental reasons. Whether movement is forced or voluntary and whether motivated by environmental or economic reasons encompasses a primary debate in the scientific literature on environmental migration (Bates 2002).

Additionally, because these definitions constitute legal classifications, identifying which category a population falls into can carry with it particular sets of entitlements or binding policy responses. For example, the UN High Commission on Refugees provides aid and resources to refugees according to their definition of refugees (Gill 2010). Accordingly, environmentally displaced populations may not be eligible for aid as refugees as they lack a "well founded fear of being persecuted" as outlined in the UN Convention Relating to the Status of Refugees. Without the inclusion of natural disasters or climate-related environmental degradation as forms of persecution, those displaced from these causes do not constitute refugees per this definition (Bronen et al. 2009; Warner et al. 2010). Despite this understanding from the UN, many studies have used the term environmental refugees to describe those displaced by environmental factors (Bates 2002; Myers 2002).

\subsubsection{Measurement}

A particular scientific implication of the definitional issues relating to environmental migration is the capacity to measure and predict flows of environmental migrants (per IOM definition). Data and empirical studies on environmental migration differ based 


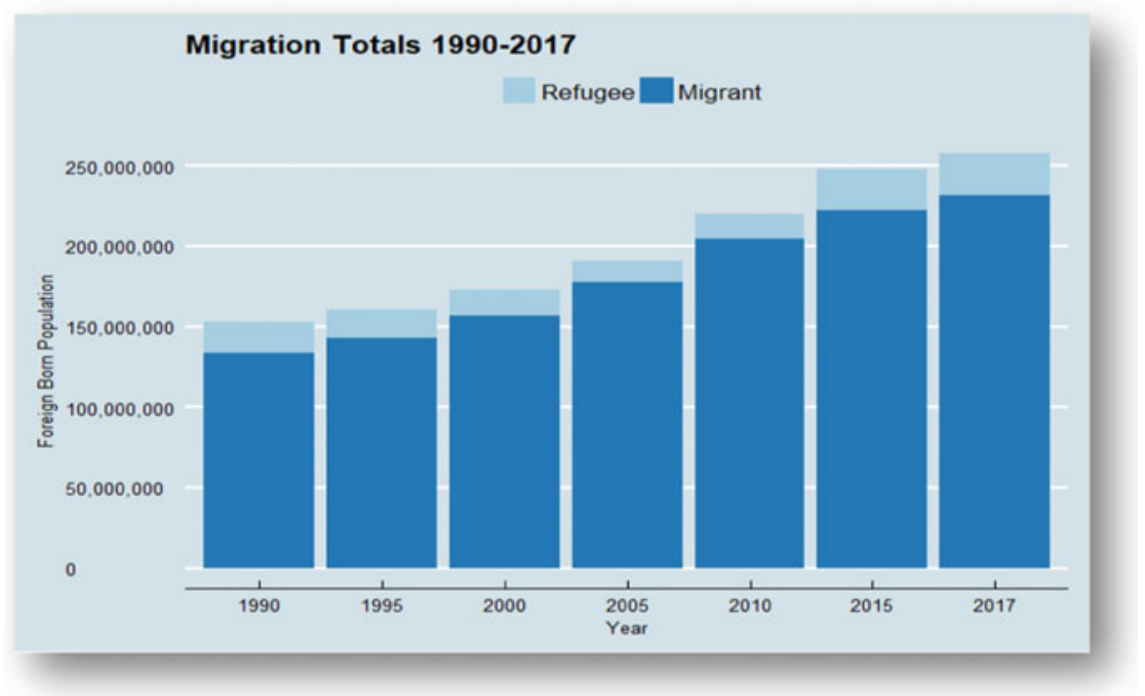

Fig. 10.3 Migration totals, measured as total foreign-born population. Data Source United Nations Population Division (2017)

on the criteria used to identify population movements as voluntary versus forced and environmentally or otherwise motivated.

Looking at international migration generally, data indicate increasing volumes of migration, but differ depending on the means of measurement. The United Nations, measuring migration as the total foreign-born population throughout the world, identifies the number of foreign-born residents of countries to be over 250 million in 2017, with over 25 million of those categorised as refugees and asylum-seekers (United Nations Population Division 2017). Figure 10.3 presents the United Nations data measuring the number of people living outside their country of birth, showing significant increases over the past 25 years.

While for foreign-born populations, there is readily available data, studies challenge this operationalisation of migration, as it fails to capture when people moved and from where. Abel and Sander (2014), for instance, estimate the volume of migration flows and direction since 1990, finding that while the stock of foreign-born populations globally has increased, there has not been a drastic increase in the flow of migrants in recent years, relative to the global population size or in absolute quantities. These differences in measurement paint very different pictures regarding contemporary global migration, with popular narratives often following UN data, shown in Fig. 10.3, indicating massive increases in migrants.

The process of measurement and analysis is further complicated when attempting to determine the cause of the movement.

Determining the proportion of international migrants who relocate due to environmental changes faces the same challenges as estimating migrant flows, with the 


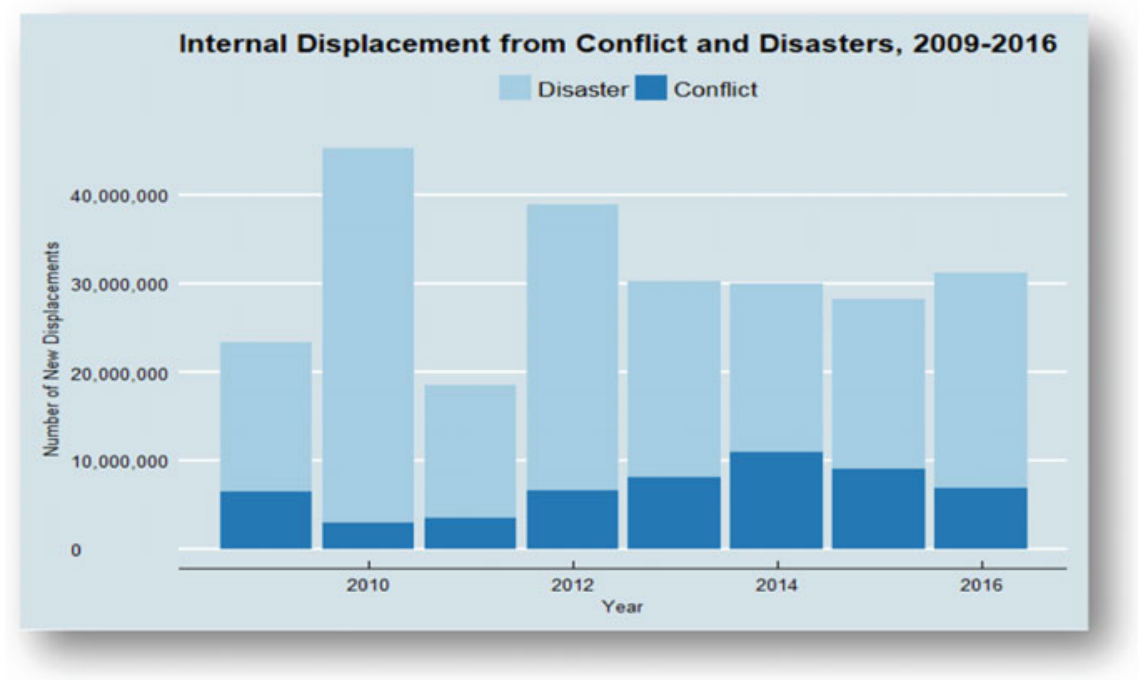

Fig. 10.4 New internal displacements per year from conflict and natural disasters. Data Source Internal Displacement Monitoring Centre 2016

additional challenges of parsing environmental motivators from economic, social, and political factors, which influence migration decisions in tandem (Black et al. 2011). Due to this complexity, as well as uncertainty in predicting future adaptive capacity, predictions of future movements of people from climate change and environmental causes vary from 25 million to 1 billion in 2050 (IOM 2017b).

In addition to international movement, populations move internally in massive numbers in the face of environmental factors, including those affected by climate change, such as natural disasters, environmental degradation, droughts, and floods. The Internal Displacement Monitoring Centre estimates the number of new internal displacements per year at values far above those estimates of international migration flows calculated by Abel and Sander (2014). As shown in Fig. 10.4, the number of internal displacements in 2016 was over 30 million. Of those displaced in 2016, nearly 25 million were displaced by natural disasters, with large volumes of displacements occurring in Asia, particularly China, India, and Pakistan, illustrated in Fig. 10.5 (IDMC 2017).

The current volume of displacements, internal and international, due to environmental stressors is striking. With climate change increasing extreme weather events as well as long-term climate variability, the IPCC finds evidence that current migration is partly driven by climate change and projects an increased displacement of people over the 21 st century, yet assigns low confidence to quantitative projections (IPCC 2014). 


\section{Total Internally Displaced by Natural Disasters, 2008-2016}

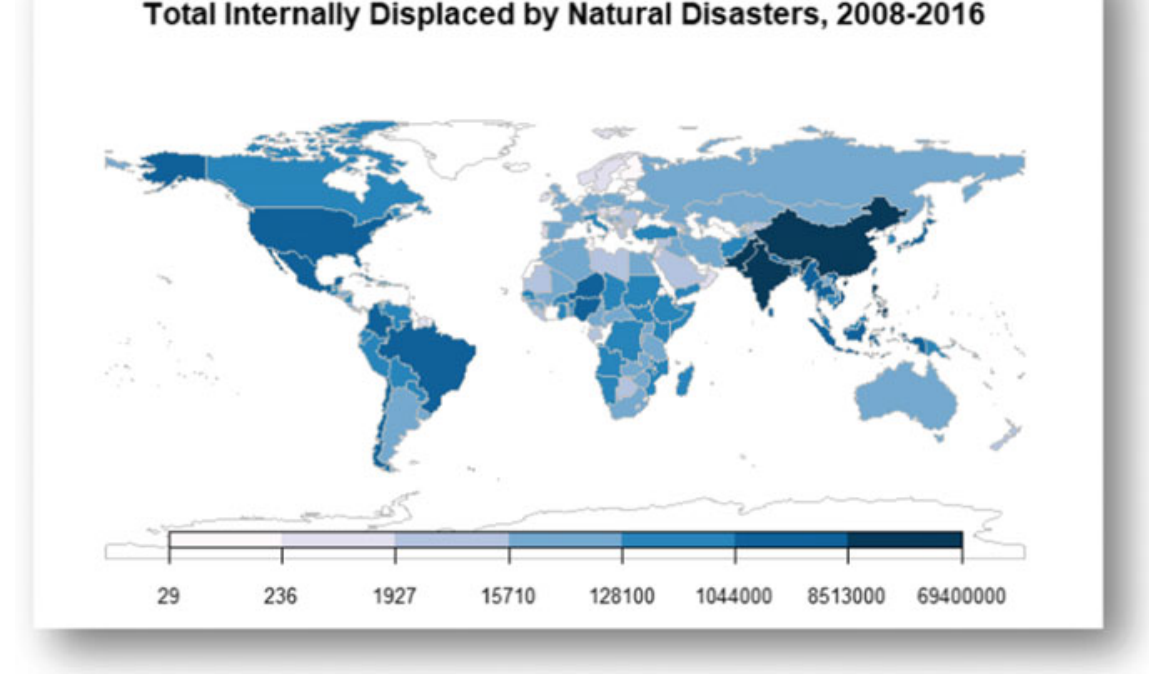

Fig. 10.5 Total number of new internally displaced by natural disasters 2008-2016. Data Source Internal Displacement Monitoring Centre 2016

\subsection{Understanding Resettlement}

Whether internal or international, the effects of displacement continue much beyond the moment of departure, and as such we briefly address the literature on the process of resettlement. This section provides an overview of the spaces and challenges faced by the displaced in the process of resettling, including those for the voluntary migrant as well as the refugee.

The figure of the voluntary migrant is often cast as one motivated by rational choices and systematic decisions. While conversations regarding refugees are framed largely through questions of the right to asylum and the politics of conflict, the migration question is consumed by questions regarding their capacity to contribute to the health and success of the local economy without detracting from local employment or host community culture (Deckard and Heslin 2016). The framing of migration in terms of economic contribution categorises the desirability and, subsequently, legality of migrants in a space (Golash-Boza 2015). Thus, anticipating the ways in which environmental migrants are received by a host country is a matter of understanding the economic desirability of that specific group in the country, which is subject to change with variations in the economic situation of the receiving area or country.

In the United States, for example, immigrants of Hispanic and Latino origin - often crossing the nation's Southern border escaping a difficult-to-disentangle combination of degraded natural resources, corruption, gang violence and economic disarray (Bender and Arrocha 2017)—represent a significant source of migrant labor 
to the nation and are associated with cheap, unskilled labor in the national discourse (Romero 2006). The inclusion of these migrants is metered by the degree to which they are seen as contributing to the national economy (Deckard and Browne 2015). This reality has become so anchored in the hegemonic common sense that a criminality has been constructed around migrant bodies, which are physically present while economically surplus (Gunkel and González Wahl 2012). To the degree to which migrants are seen as costing money in terms of social benefits or use of public goods, they are viewed as members of an out-group. Conversely, to the extent that they are perceived to work effectively and contribute to the general economic well-being, they are seen as meritorious of inclusion in national communities (Armenta 2017; Golash-Boza and Parker 2007).

The discourse around migrant labor is similar in other wealthy nations-most notably the construction of the African in Western Europe. Similar to the push factors propelling Latino immigrants to the United States, the home country realities of the French sans papiers vary in their combination of environmental degradation, conflict, economic hardship and corruption. Also, similarly undocumented migrants to France exist in the interstices of surplus labor and criminal (Schaap 2011). In sharp contrast to the extensive positive attention given to methods of incorporation for refugees and legal migrants - those who have been given permission to reside in the nation only so long as they perform work explicitly required in order to meet national economic goals - any need to integrate the economically surplus generated by global challenges has, apparently, been addressed with their widespread criminalisation.

In addition to the flows of voluntary migrants internally and internationally, mass events, such as natural disasters, can abruptly displace those living in a space, often en masse. When such large and sudden displacements occur, governments face logistical and political challenges in managing the flow of people internally and across international borders. In this process, the displaced can seek asylum, often settling temporarily in refugee camps, beginning a prolonged, indefinite state of transience.

Understanding the role and structure of the refugee camp is an important component of environmental migration, as refugee camps represent the political response to mass displacement, as possible through large scale natural disasters. Through such events, as well as large scale conflicts, displaced populations can flow into neighbouring countries at rates, which exceed the economic, political, or social capacity or willingness of the receiving country to accommodate. The structure of the camp itself speaks to its roots in political expediency for the host country. Following the established provisions in the 1951 Convention Relating to the Status of Refugees and 1967 Protocol, to maintain credibility globally, countries face international pressure to respond to mass displacement (Black 2001). The refugee camp thus arises out of the juxtaposition of the international pressure to act charitably towards those in need and a state's inclination to keep "space and distance" from the refugees themselves (Hyndman 2000).

In addressing the losses and damages of environmental displacement, one must engage with the realities of the refugee camp. Rather than initiating a process of assimilation, the camp inherently exists as a space of prolonged temporality, which serves to exclude refugees' participation in the economic and social activities of the 
host country, as well as from political representation and participation (Kibreab 2003; Ramadan 2013). Further, refugee initiatives are often conducted with limited input from the supposed beneficiaries of the aid (Silverman 2008; Hanafi and Long 2010), thereby inhibiting the development of refugee communities into societal structures of the host country and of the global economy at large (Hanafi and Long 2010). In contrast to refugee camps, asylum policies aim to initiate the process of resettlement for displaced persons. An asylum-seeker is one who has applied for refuge outside their own country and is awaiting official refugee status in their new country of residence. The refugee camp dweller is often not distinct from the asylum seeker, as applications for asylum start once an individual has arrived in a refugee camp, but also can begin following arrival to a host country legally by obtaining a work or student visa.

Asylum-seekers, however, face many barriers in the process of resettlement. First, because of bureaucratic process and the sheer number of applicants, central to the experience of the twenty first century asylee is the experience of years of waiting (Rotter 2016). The asylum-seeking process also requires costs associated with travel and paperwork fees, often making resettlement inaccessible to many whose livelihoods depend on it (Settlage 2009). Additionally, due to host citizens' belief that asylum-seekers take more than they give socially, destination countries may be less than welcoming in their public policy affecting accepted asylees in an effort to deter refugees from arriving. A study of the European Union indicates that countries compete in a race to the bottom for provision of services through five areas of asylum policy: 'safe third country' provisions, determination procedures, compulsory dispersal policy, welfare vouchers, and obstacles from employment (Thielemann 2004).

Critically, because the nation-state holds exclusive control over the bodies in its territory, the right of asylum following from international law is generally understood as a right for the state to grant or deny, rather than the right of an individual to claim (Boed 1994). To be granted asylum as a refugee, according to the UN 1951 Refugee Convention, one must have a "well-founded fear of being persecuted for reasons of race, religion, nationality, membership of a particular social group or political opinion" (United National 1951). As outlined above, the construction of climate-induced calamities as "natural" disasters, therefore, influences the perceived legitimacy of resulting claims to refugeehood and asylum (Shacknove 1985). That is, insofar as events such as hurricanes and droughts are interpreted as apolitical tragedies, the presumed contract between citizen and state that grounds refugee policy is never broken, thus lacking a sufficient claim of persecution.

\subsection{Case Studies of Environmental Migration}

The risks associated with climate change vary greatly between different geographic locations and different social structures (IPCC 2014). Correspondingly, the mechanisms by which climate change can influence the flow of people also vary widely from place to place, with corresponding sets of losses and damages faced by the 
affected populations at the time of departure as well as in the process of resettlement. In this section, we detail a selection of cases in which the environment plays a role in the displacement of a population, including sea-level rise, cyclonic storms, and desertification, as well as the role of deforestation as a driver of both climate change and migration. We outline examples of each, highlighting the complex set of losses and damages incurred by populations in each case.

\subsubsection{Sea-Level Rise in Pacific Island States}

The dominant media representation of Pacific Small Island Developing States (SIDS) is of drowning islands, with rising sea levels compelling residents to move (Barnett and Campbell 2010). However, this narrative is simplistic for two reasons. Firstly, while sea-level rise does cause erosion and more frequent, and intense flooding events (Nurse et al. 2014), and floods can damage property, destroy crops, contaminate water supplies and spread disease through penetrating septic tanks (ADB 2014), it is not the only climate hazard driving mobility. Changes in rainfall can combine with lack of aquifers to produce a shortage of water for bathing, drinking, cooking and agriculture (IPCC 2014) and the increase in $\mathrm{CO}_{2}$ in the atmosphere is contributing to ocean acidification, impacting on fisheries (Manzello et al. 2017). Secondly, islanders are not automatons which respond to climate change in fixed way by moving away from the sea. Instead, they have a degree of individual and collective agency to respond, and adapt to climate change (Gemenne 2011). It is also true that both climate change risk perceptions and attitudes towards mobility are nuanced and differentiated within Pacific SIDS. Recent qualitative research on Kiribati found three distinct shared viewpoints on the themes. One group seemed to exempt itself from agency in the matter, claiming that God would decide the fate of Kiribati. Another group believed that climate change would likely result in some people leaving their islands, while a final group stressed the existential threats of climate change to islands, populations and culture (Oakes et al. 2016).

Nonetheless, when the impacts of climate change interact with the physical geography and developmental status of the SIDS, human mobility can and does occur and such movements have implications for Loss and Damage, with a general trend of the more agential the movement, the less severe losses and damages. Displacement can occur when an intensive natural hazard such as a storm or flood compels people to leave their place of residence. Forcibly displaced persons have little control over when, where and how they move and as a result are more likely to be subject to losses and damages. In Kiribati, a survey revealed that almost every household (94\%) reported that they had been impacted by a natural hazard over the period 2005-2015, with sea-level rise affecting $80 \%$ of households (Oakes et al. 2016). The same study found that one in seven of all movements from 2005 to 2015 were attributed to environmental change (14\%), and the vast majority of such movements were internal (Fig. 10.6). This is despite the fact that international movement is often 


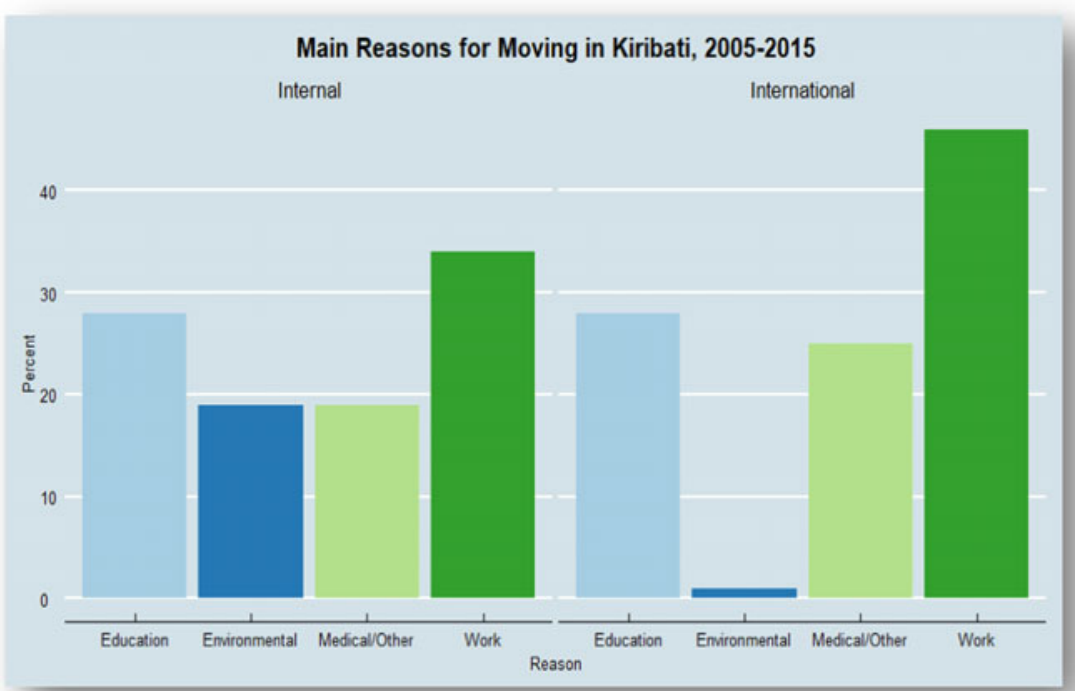

Fig. 10.6 The main reasons for moving in Kiribati 2005-2015. Source Oakes et al. (2016)

seen as desirable, suggesting a lack of choice in destination for people impacted by a climate-impacted environment.

Losses and damages suffered in the context of such climate change related displacement can be in the form of health, access to services and education, protection and culture (Unicef UK 2017). In Pacific SIDS, king tides cause frequent floods and are intensified by sea level rise and La Niña years (Lin et al. 2014). There can be very short intervals between king tides (Lin et al. 2014) meaning that households have little time to recover and can be locked into a vicious cycle of recovery. Vulnerable groups are particularly at risk. Climate change related environmental degradation has meant that children in Pacific SIDS have been forced to move to islands with more resilient infrastructure for schooling. Often this involves staying with extended families, which can place them at risk of all forms of abuse (PRRRT 2014).

Voluntary migration typically makes place as people seek more secure livelihoods less impacted by environmental hazards such as changes in rainfall, agricultural yields and fisheries. In such instances, losses and damages can be less severe. The IKiribati idea of "migration with dignity" has not been defined in a policy document, but revolves around facilitating voluntary migration through improving education and developing international networks (Voigt-Graf and Kagan 2017). In this manner, it is hoped that people can migrate, generating remittances to enable adaptation (IOM 2017a) improve their livelihoods (Gemenne and Blocher 2017) and in so doing reduce future losses and damages inducing displacement. However, in both Kiribati (Oakes et al. 2016) and Tuvalu (Milan et al. 2016) international migration is limited by finances and permits. In the absence of options to move internationally, the major- 
ity of internal movements in these countries are to the capital cities, contributing to overcrowding and threatening the attainment of the Sustainable Development Goals and other development targets, especially those related to sanitation (Locke 2009; ADB 2014; Oakes et al. 2016). Such urbanisation may therefore be termed maladaptive as it can increase both vulnerability and exposure to hazards (de Sherbinin 2013). Planned relocation in SIDS takes place when the state or other authority organises the re-settlement of communities out of harm's way, often because of encroachment by the ocean (Charan et al. 2017). Stratford et al. (2013) explain how the Tuvaluan word "Fenua" is useful for describing the concept of place for communities in Pacific SIDS:

A set of customary practices and territorial markers, fenua captures the ways in which Pacific community identity is usually linked to part of an island—such as a valley or bay-and explains the biographical location of identity in place. Fenua is a term that indistinguishably bundles together community/people/places. (Stratford et al. 2013:69)

Fenua therefore explains how culture and life itself is often inextricable from the land, island or part of the island of a people and goes some way to explaining the complexity inherent in relocations. Throughout the 20th century various relocations took place within the Pacific region, many of which were unsuccessful for not considering livelihoods or cultural differences (Connell 2012) and even possibly contributing to deaths as people were exposed to new environmental risks (Donner 2015). Unsurprisingly, proposed relocations have been rejected by the moving community (Tabucanon and Opeskin 2011). Some people are reticent to move as potential migrants feel that they will lose a link to their past and their very cultural identity (Mortreaux and Barnettt 2009). As a result, moving from home can bring feelings of grief and anxiety (Doherty and Clayton 2011) and people may stay in objectively risky areas (Oakes et al. 2016). Some recent relocations have been more successful where processes are participatory and consideration is given to culture and livelihoods (Tabucanon 2012). Guidelines of good practice have been produced to improve the experiences of those who relocate which may contribute to better results for both relocating and host communities (Brookings and UNHCR 2015), thereby minimising losses and damages.

\subsubsection{Cyclonic Storms}

Cyclonic storms affect tropical and subtropical regions, in the Atlantic, Caribbean and North-East Pacific as hurricanes and in North-West Pacific as typhoons and the South Pacific and Indian Ocean as cyclones. It is impossible to link a particular storm to climate change, and globally with increased temperatures, less storms could form due to changes in wind shear (Vecchi and Soden 2007). Nonetheless climate change will likely result in higher risk from cyclones through increased average sea temperatures causing more intense and wetter storms and sea-level rise magnifying the impact of storm surges - the main killer in cyclones (IPCC 2012). These climatic changes are 
occurring at the same time as economic and demographic changes, which result in larger, more vulnerable populations living in more exposed areas (Hugo 2011). As a result, globally millions of people are affected each year, with 12.9 million people displaced by storms in 2016 (IDMC 2017). Whether human mobility related to a cyclone is before or after the event, the losses and damages can be extensive.

Poorer countries are typically more exposed to cyclonic storms due to their locations in tropical regions and more vulnerable to their impacts due to poverty, livelihoods dependent on natural resources and low levels of education and healthcare (Blaikie et al. 2014). Bangladesh is low-lying and deltaic meaning that each year millions of vulnerable people are living in areas exposed to cyclones and floods. As such, according to the World Risk Index, in 2016 Bangladesh was the 5th most at risk country in the world (Garschagen et al. 2016). Although Bangladesh has early warning systems, these do not always grant sufficient time for people to leave in a manner to minimise losses and damages. Moreover, some people may stay to protect their livelihoods (Ayeb-Karlsson et al. 2016). There are also cultural barriers which may contribute to non-evacuation. Some people may be fatalistic about cyclones and conceptualise evacuation as against Allah's will (Haque 1995). Unaccompanied women might not go to the cyclone shelter, as it can be culturally taboo (Paul 2014). In cyclone shelters, and on the journey to them, women and children are at risk of disease through insanitary conditions and may even cause themselves harm through reluctance to go to the toilet in public (Unicef UK 2017).

After repeated displacements Bangladeshis may move either seasonally or permanently (Unicef UK 2017), making Dhaka one of fastest growing city in the world with residents subject to losses and damages. Almost half the population of Dhaka lives in slums where approximately a third have no access to sanitation (World Bank 2015) and are exposed to communicable disease (Banu et al. 2013). Children in Dhaka presented a significantly higher number of disability-adjusted life years (DALYs) than children who had not been displaced (Molla et al. 2014). Seasonal or permanent migration to a city can bring new or increased risks related to working conditions (Ayeb-Karlsson et al. 2016) and children can miss out on school if they are obliged to find work (Unicef UK 2017).

Rich countries are not immune to losses and damages associated with mobility related to cyclonic storms. The USA is frequently impacted by hurricanes, with 875,000 people displaced by Hurricane Matthew in 2016 (IDMC 2017). By midOctober, the 2017 Atlantic hurricane season had produced 15 storms, 10 hurricanes and 5 major hurricanes, while the month of September 2017 was the single most active month for Atlantic storms on record (The Weather Channel 2017). Projections for the North Atlantic show a $45 \%$ increase in the number of major hurricanes (category 3 or above) in the period 2016-2035 relative to 1986-2005 and an 11\% increase in related rainfall (Knutson et al. 2010). Hurricanes Irene and Sandy in 2011 and 2012 respectively may provide evidence of a shift in the hurricane belt (IPCC 2012), which could have implications for a population lacking the experience and infrastructure to cope with hurricanes (Cutter et al. 2007).

The poorest and ethnic minority communities are typically those which suffer the most severe losses and damages through hurricane displacement. The natural 
and man-made processes which combined for Hurricane Katrina, meant that some termed the disaster "death by political economy" for the African America residents of Louisiana (Price 2008). Children are also more likely to be affected by hurricane displacement. Children displaced by Hurricane Katrina were five times more likely to suffer from emotional distress (Abramson et al. 2010) and those in a state of prolonged displacement and unable to return to the city were more likely to suffer from post-traumatic stress disorder and depression than those who moved within the city (Hansel et al. 2013). Over a third of children displaced by Hurricane Katrina were a year or more behind in school (Abramson et al. 2010). There were also ramifications on school behaviour, attendance, suspension, expulsion and drop-out rates (Pane et al. 2006; Ward et al. 2008).

In the USA, typically 20-30\% of the affected populations fail to respond to evacuation orders and remain in the disaster area during storms (Redlener 2006). This can be attributed to differentiated risk perception, others fail to evacuate prior to the landfall of the hurricane to avoid perceived losses and damages that leaving entails. Reasons for not evacuating include the discomfort for elderly or infirm (Van Willigen et al. 2002) protecting one's home from looters (Riad et al. 1999), previous problems with evacuation traffic (Morss and Hayden 2010), anxiety about being arrested for undocumented workers (Tiefenbacher and Wilson 2012), reluctance to leave pets (Heath et al. 2001) and the need to be able to clean up after the storm as soon as possible (Dash and Morrow 2000).

\subsubsection{The Desertification of West Africa and the Ascendance of Boko Haram}

Natural disasters - however unnatural - are not the only movers of people across nations and regions. The changing terrain that accompanies widespread climate change also shifts geo-political realities, and with them the landscape of conflict. Here, we consider the ways in which slowly-worsening environmental conditions change people's locations and lives, specifically desertification and deforestation.

Desertification has made previously fertile agricultural land functionally uninhabitable in regions throughout the world (Bettini and Andersson 2014; Owusu 2013; Vieira et al. 2015). Existing research has linked this phenomenon to man-made climate change for nearly 25 years (Hulme and Kelly 1993; Calabrò and Magazù 2016). In the case of the Sahara, it has made already tenuous post-colonial regimes even more vulnerable, as fragile states struggle to maintain basic services while grappling with the arrival of citizens and migrants in transit (Ferris 2012). Traditional ways of life have been rendered obsolete as villages are overtaken by the sand of the Sahel and, in the case of Nigeria, the trend has worked to further impoverish the Northern provinces of the nation (Mantzikos 2010). In the Maiduguri province of Northern Nigeria, school teachers were unable to cultivate land or fish during school breaks. This newly found desperation contributed to their organising of students into the rad- 
ical Islamist organisation referred to as Boko Haram (Deckard et al. 2015; Walker 2012).

With the rise of Boko Haram has come relentless attacks against Nigerian secular institutions-especially in the North (Mohammed 2014; Agbiboa 2013). Actual deaths since 2009 number approximately 100,000 (Tukur 2017), and churches (Michael Kpughe 2017), schools (Aghedo and Osumah 2012) and public spaces (Maiangwa et al. 2012) have all been targeted. The relentless violence has been met by similar attacks by the Nigerian military-resulting in thousands more civilian casualties. As of 2017, Boko Haram has displaced an estimated two million Northern Nigerians, sending families fleeing throughout Nigeria and into the neighbouring countries of Chad and Cameroon (Tukur 2017). Certainly, the actions of individual Boko Haram and Nigeria military members are to blame for this displacement, but also worth understanding is the way in which slow-moving environmental degradation has contributed to the conflict between the two parties, and subsequent displacement of millions. In the stories of the displaced, there is much discussion of deteriorating conditions and a wish to return to not only the geographical home-but the traditional one (Jacob et al. 2016). Given the realities of climate change, however, this traditional home may be considered a fictive one, as livelihoods are no longer sustainable.

\subsubsection{The Deforestation of the Southern Cone and the Urbanisation of the Campesino}

In the consideration of climate change as a driver of migration, we can see the ways in which natural disasters and sea-level rise displace populations, as well as consequences of damages to traditional livelihoods in the case of Nigeria. In addition to examples of displacement and conflict relating to climate change, there are development-related phenomena that are causal agents of climate change, while also working to drive migration. In such cases, as people are systematically moved, the land is cleared for further development, spurring both climate change at the local and global level and a continued feedback loop of migration and further development. Here, we treat the specific issue of monoculture-propelled deforestation in South America's Southern Cone-a documented cause of the type of slow-moving climate change that pushes intergenerational movement (Bonan 2008).

Soybean monoculture increasingly defines the landscape of the Southern Cone and the lives of the people in it (Oliveira and Hecht 2016). The link between soy, deforestation and changing climate is well-documented in both the scholarly literature and the collective memory of communities torn apart by soy (Fehlenberg, et al. 2017; Hetherington 2011). As deforestation continues apace, realities for peasant campesinos in Paraguay, Argentina, and Brazil are being upended (Fair 2011).

In response to their wholesale dispossession at the hands of agribusiness and with the collusion of the various national governments, campesinos have been migrat- 
ing - both to urban areas within their own countries and abroad Parrado and Cerrutti (2003). The Paraguayan case is particularly instructive, given the nation's status as a paradigm of neoliberal governance in its post-dictatorship (Nickson and Lambert 2002; Ezquerro-Cañete 2016). As the state's "hands off" approach to both exportoriented agribusiness and migration has allowed the results of deforestation to affect the nation's social dynamics in a way that is largely uninfluenced by regulation or legislation.

Paraguayan campesinos overwhelmingly relocate to informal settlements in the nation's three largest urban centres (Hetherington 2011; Reed 2015). These slum areas, known as bañados, are completely without the presence of the state-with dwellings having no reliable access to power, no mailing addresses and complying with no legal building codes (Reed 2015; Cunningham et al. 2012). Despite the presence of privately built streets of various quality, the communities do not appear on maps. As indicated by the nomenclature, bañados are located in flood plains-leaving the residents to evacuate to public parks and street corners on higher ground in times of flood (Hetherington 2011). Although bañados have no permanent infrastructure, residences are inhabited multi-generationally, with adults in 2017 living with their children in the most desirably located bañado homes constructed by the grandparents as early as the 1930s. Although the families may be understood as displaced, their current homes are permanently in temporary spaces, and their government has no demonstrated intention of changing this reality.

\subsection{Conclusions}

As climate change continues to put at risk the livelihoods and personal security of populations throughout the world, the movement of people internally and across international borders will continue. Due to the numerous consequences of climate change and the ways climate change interacts with other environmental stressors and existing social structures, the pathways by which changes in climate displace populations differ greatly between places, overlapping in ways specific to a particular locale. In this chapter, we outlined examples of these overlapping climate risks in locations including Pacific Small Island Developing States, West Africa and the Southern Cone, highlighting the complex interactions between the environment, natural resources, extreme weather, and society. With the push of populations away from their homes through sea-level rise, cyclones, desertification, or other environmental change, we draw attention to the ways in which displaced populations are received and the challenges they face in resettlement. This piece is critical for understanding the losses and damages associated with dislocation, as risks to displaced populations do not end once they have left their homeland. Studies of climate-related displacement must address where people move to and how the political economy of the sending and receiving nations affects the capacity of migrants to resettle and succeed in their new country. Additionally, in considering future climate change and its effects on populations, we must also acknowledge that in the face of losses and 
damages to livelihoods and safety, not all are able to relocate. Studies of climateinduced migration will also need to take into account those left behind and whether they have sufficient resources to address future damages from climate change. In this way, future studies of climate and displacement must include both the process of leaving and resettling, as covered here, as well as an investigation into the standard of living for those who remained.

\section{References}

Abel GJ, Sander N (2014) Quantifying global international migration flows. Science 343:1520-1522 Abramson DM, Park YS, Stehling-Ariza T Redlener I (2010) Children as bellwethers of recovery: dysfunctional systems and the effects of parents, households, and neighborhoods on serious emotional disturbance in children after Hurricane Katrina. Disaster Med Public Health Preparedness 4(Suppl 1):S17-27

Agbiboa D (2013) The ongoing campaign of terror in Nigeria: Boko Haram versus the state. Stability: Int J Security Develop 2(3):1-18

Aghedo I, Osumah O (2012) The Boko Haram uprising: how should nigeria respond? Third World Q 33(5):853-869

Armenta A (2017) Racializing crimmigration: structural racism, colorblindness, and the institutional production of immigrant criminality. Sociol Race Ethnic 3(1):82-95

Asian Development Bank (ADB) (2014) Economic costs of inadequate water and sanitation: South Tarawa. Kiribati, Asian Development Bank

Ayeb-Karlsson S, Geest K, Ahmed I, Huq S, Warner K (2016) A people-centred perspective on climate change, environmental stress, and livelihood resilience in Bangladesh. Sustain Sci 11(4):679-694

Banu S, Rahman MT, Uddin MKM, Khatun R, Ahmed T, Rahman MM, Husain MA, van Leth F (2013) Epidemiology of tuberculosis in an urban slum of Dhaka City, Bangladesh. PloS one 8(10):e77721. https://doi.org/10.1371/journal.pone.0077721

Barnett J, Campbell J (2010) Climate change and small island states: power, knowledge, and the South Pacific. Earthscan, London

Bates DC (2002) Environmental refugees? Classifying human migrations caused by environmental change. Popul Environ 23(5):465-477

Bender SW, Arrocha WF (2017) Introduction. In: Bender SW, Arrocha WF (eds) Compassionate migration and regional policy in the Americas. Palgrave Macmillan UK, London, pp 1-15

Bettini G, Andersson E (2014) Sand waves and human tides: exploring environmental myths on desertification and climate-induced migration. J Environ Develop 23(1):160-185

Black R (2001) Fifty years of refugee studies: from theory to policy. Int Migr Rev 35(1):57-78

Black R, Bennett SRG, Thomas SM, Beddington JR (2011) Climate change: migration as adaptation. Nature 478:447-449. https://doi.org/10.1038/478477a

Blaikie P, Cannon T, Davis I, Wisner B (2014) At risk: natural hazards, people's vulnerability and disasters. Routledge, Oxon

Boed R (1994) The state of the right of asylum in international law. Duke J Compar Int Law $5(1): 1-34$

Bonan GB (2008) Forests and climate change: forcings, feedbacks, and the climate benefits of forests. Science 320(5882):1444-1449

Bronen R, Chandrasekhar D, Conde D, Kavanova K, Caro Morinière L, Schmidt K, Witter R (2009) Stay in place or migrate: a research perspective on understanding adaptation to a changing environment. In: Oliver-Smith A, Shen X (eds) Linking environmental change, migration and 
social vulnerability, studies of the university: research. Edication-Publication Series of the UNU-ERS, Counsel, pp 12-21

Brookings \& UNHCR (2015) Guidance on Planned Relocation. http://www.unhcr.org/uk/protecti on/environment/562f798d9/planned-relocation-guidance-october-2015.html

Calabrò E, Magazù S (2016) Correlation between increases of the annual global solar radiation and the ground albedo solar radiation due to desertification - a possible factor contributing to climatic change. Climate 4(4):64

Charan D, Kaur M, Singh P (2017) Customary land and climate change induced relocation-a case study of Vunidogoloa Village, Vanua Levu, Fiji. In Climate Change Adaptation in Pacific Countries. Springer International Publishing, pp 19-33

Connell J (2012) Population resettlement in the Pacific: lessons from a hazardous history? Aust Geogr 43(2): 127-142

Cunningham R, Simpson C, Keifer M (2012) Hazards faced by informal recyclers in the squatter communities of Asunción, Paraguay. Int J Occup Environ Health 18(3):181-187

Cutter SL, Johnson LA, Finch C, Berry M (2007) The U.S. Hurricane coasts: increasingly vulnerable? Environ: Sci Policy Sustain Develop 49(7):8-21

Dash N, Morrow B (2000) Return delays and evacuation order compliance: the case of Hurricane Georges and the Florida Keys. Global Environ Change Part B: Environ Hazards 2(3):119-128

de Sherbinin A (2013) Climate change hotspots mapping: what have we learned? Clim Change 123(1):23-37

Deckard ND, Barkindo A, Jacobson D (2015) Religiosity and Rebellion in Nigeria: considering Boko Haram in the radical tradition. Stud Conflict Terrorism 37(7):510-528

Deckard ND, Browne I (2015) Constructing citizenship: framing unauthorized immigrants in market terms. Citizsh Stud 19(6-7):664-681

Deckard N, Heslin A (2016) After postnational citizenship: constructing the boundaries of inclusion in neoliberal contexts. Sociol Compass 10(4):294-305

Doherty TJ, Clayton S (2011) The psychological impacts of global climate change. Am Psychol 66(4):265

Donner SD (2015) The legacy of migration in response to climate stress: learning from the Gilbertese resettlement in the Solomon Islands. Nat Res Forum 39(3-4):191-201

Dun O, Gemenne F (2008) Defining environmental migration. Forced Migr Rev 31(October):10-11

Ezquerro-Cañete A (2016) Poisoned, dispossessed and excluded: a critique of the neoliberal soy regime in Paraguay. J Agrarian Change 16(4):702-710

Fair EM (2011) The peasantary with modern capitalism: power, position, and class. The Global Labour University, London

Fehlenberg V, Baumann M, Ignacio N, Piquer-Rodrigueza M, Gavier-Pizarrod G, Kuemmerle T (2017) The role of soybean production as an underlying driver of deforestation in the South American Chaco. Glob Environ Change 45:24-34

Ferris E (2012) Internal displacement in Africa: an overview of trends and opportunities. BrookingsLSE Project on Internal Displacement, New York, pp 1-12

Garschagen M, Hagenlocher M, Comes M, Dubbert M, Sabelfeld R, Lee YJ, Grunewald L, Lanzendörfer M, Mucke P, Neuschäfer O, Pott S (2016) World Risk Report 2016

Gemenne F (2011) Why the numbers don't add up: a review of estimates and predictions of people displaced by environmental changes. Glob Environ Change 21(S1):41-S49

Gemenne F, Blocher J (2017) How can migration serve adaptation to climate change? Challenges to fleshing out a policy ideal. Geogr Journal 183(4):336-347

Gill N (2010) 'environmental refugees': Key debates and the contributions of geographers. Geography Compass 4:861-871

Golash-Boza T (2015) Deported: immigrant policing. NYU Press, Disposable Labor and Global Capitalism

Golash-Boza T, Parker D (2007) Human Rights in a globalizing world: who pays the human cost of migration? J Latino/Latin American Stud 2(4):34-46 
Gunkel SE, González Wahl A-M (2012) Unauthorized migrants and the (Il)Logic of "Crime Control": a human rights perspective on us federal and local state immigration policies. Sociol Compass 6(1):26-45

Hanafi S, Long T (2010) Governance, governmentalities, and the state of exception in the Palestinian refugee camps of Lebanon. J Refugee Stud 23(2):135-159

Hansel TC, Osofsky JD, Osofsky HJ, Friedrich P (2013) The effect of long-term relocation on child and adolescent survivors of Hurricane Katrina. J Trauma Stress 26(5):613-620

Haque CE (1995) Climatic hazards warning process in Bangladesh: experience of, and lessons from, the 1991 April cyclone. Environ Manage 19(5):719-734

Heath SE, Kass PH, Beck AM, Glickman LT (2001) Human and pet-related risk factors for household evacuation failure during a natural disaster. Am J Epidemiol 153(7):659-665

Hetherington K (2011) Guerrilla auditors: the politics of transparency in neoliberal Paraguay. Duke University Press, Durham, NC

Hulme M, Kelly M (1993) Exploring the links between desertification and climate change. Environ: Sci Policy Sustain Develop 35(6):4-45

Hugo G (2011) Future demographic change and its interactions with migration and climate change. Glob Environ Change 21(S1):S21-S33

Hyndman J (2000) Managing displacement: refugees and the politics of humanitarianism. University of Minnesota Press, Minneapolis, MN

IDMC (2016) Global Internal Displacement Database. Internal Displacement Monitoring Centre

IDMC (2017) Global Report on Internal Displacement. Internal Displacement Monitoring Centre

IPCC (2012) Managing the risks of extreme events and disasters to advance climate change adaptation: special report of the intergovernmental panel on climate change. Cambridge University Press, Cambridge and New York

IPCC (2014) Climate change 2014: impacts, adaptation, and vulnerability-Part A: global and sectoral aspects. In: Field CB and others (eds) Contribution of working group II to the fifth assessment report of the intergovernmental panel on climate change. Cambridge University Press, Cambridge and New York

IOM (2017a) Making mobility work for adaptation to environmental changes: results from the MECLEP global research. International Organization for Migration, Geneva

IOM (2017b) Migration, climate change and the environment: a complex nexus. International Organization for Migration, Geneva

IOM (2017c) Migration, climate change and the environment: definitional issues. International Organization for Migration, Geneva

IOM (2018) Key migration terms. International Organization for Migration, Geneva

Jacob JU-U, Abia-Bassey M, Nkanga E, Aliyu A (2016) Narratives of displacement: conversations with boko haram displaced persons in Northeast Nigeria. Contemporary French and Francophone Studies 20(2):176-190

Kibreab G (2003) Displacement, host governments' policies, and constraints on the construction of sustainable livelihoods. Int Soc Sci J 55(175):57-67

Knutson TR, McBride JL, Chan J, Emanuel K, Holland G, Landsea C, Held I, Kossin JP, Srivastava AK, Sugi M (2010) Tropical cyclones and climate change. Nat Geosci 3:157-163

Lin CC, Ho CR, Cheng YH (2014) Interpreting and analyzing King Tide in Tuvalu. Nat Hazards Earth Sys Sci 14(2):209-217

Locke JT (2009) Climate change-induced migration in the Pacific region: sudden crisis and longterm developments. Geogr J 175(3):171-180

Maiangwa B, Uzodike UO, Whetho A, Onapajo H (2012) "Baptism by Fire": Boko Haram and the Reign of Terror in Nigeria. Africa Today 59(2):40-57

Mantzikos I (2010) The absence of the state in Northern Nigeria: the case of Boko Haram. Afr Renaissance 7(1):57-62

Manzello DP, Eakin CM, Glynn PW (2017) Effects of global warming and ocean acidification on carbonate budgets of eastern pacific coral reefs. In: Glynn PW, Manzello DP, Enouchs IC 
(eds) Coral reefs of the eastern tropical Pacific: persistence and loss in a dynamic environment. Springer, Netherlands, pp 517-533

Michael Kpughe L (2017) Christian churches and the Boko Haram insurgency in cameroon: dilemmas and responses. Religions 8(8):143

Milan A, Oakes R, Campbell J (2016) Tuvalu: climate change and migration-relationships between household vulnerability, human mobility and climate change Report No.18. Bonn: United Nations University Institute for Environment and Human Security (UNU-EHS). http://collections.unu.e du/view/UNU:5856

Mohammed K (2014) The message and methods of Boko Haram. In: de Montclos MP (ed) Boko Haram: Islamism, politics, security and the State in Nigeria. African Studies Centre - Institut Français de Recherche en Afrique (IFRA), Leiden, Netherlands, pp 9-32

Molla NA, Mollah KA, Fungladda W, Ramasoota P (2014) Multidisciplinary household environmental factors: influence on DALYs lost in climate refugees community. Environ Develop 9:1-11

Morss RE, Hayden MH (2010) Storm Surge and 'Certain Death': interviews with texas coastal residents following Hurricane Ike. Weather Clim Soc 2:174-189

Mortreux C, Barnett J (2009) Climate change, migration and adaptation in Funafuti, Tuvalu. Global Environ Change 19(1):105-112

Myers N (2002) Environmental refugees: a growing phenomenon of the 21st century. Phil Trans R Soc Lond B 357:609-613

Nickson A, Lambert P (2002) State reform and the 'Privatized State' in Paraguay. Public Admin Develop 22(2):163-174

Nurse LA, McLean RF, Agard J, Briguglio LP, Duvat-Magnan V, Pelesikoti N, Tompkins E, Webb A (2014) Small islands. In: Climate change 2014: impacts, adaptation, and vulnerability. Part B: regional aspects. Contribution of working group II to the fifth assessment report of the Intergovernmental Panel on Climate Change. Barros VR, Field CB, Dokken DJ, Mastrandrea MD, Mach KJ, Bilir TE, Chatterjee M, Ebi KL, Estrada YO, Genova RC, Girma B, Kissel ES, Levy AN, MacCracken S, Mastrandrea PR, White LL (eds.). Cambridge University Press, Cambridge, United Kingdom and New York, NY, USA, pp. 1613-1654

Oakes R, Milan A, Campbell J (2016) Kiribati: climate change and migration-relationships between household vulnerability, human mobility and climate change. Report No. 20. Bonn: United Nations University Institute for Environment and Human Security (UNU-EHS). http://c ollections.unu.edu/view/UNU:5903

Obokata R, Veronis L, McLeman R (2014) Empirical research on international environmental migration: a systematic review. Popul Environ 36:111-135

Oliveira G, Hecht S (2016) Sacred Groves, Sacrifice Zones and soy production: globalization, intensification and neo-nature in South America. J Peasant Stud 46(2):251-285

Owusu AB (2013) Measuring desertification in continuum: normalized difference vegetation indexbased study in the upper east region, Ghana. Civil Environ Res 3(12):157-170

Pacific Regional Rights Resource Team (PRRRT) (2004) Commercial sexual exploitation of children and child sexual abuse in the Republic of Kiribati: a situation analysis. Tarawa, Kiribati: United Nations Children's Fund (UNICEF)

Pane JF, McCaffrey DF, Tharp-Taylor S, Asmus GJ, Stokes BR (2006) Student displacement in Louisiana after the hurricanes of 2005: experiences of public schools and their students. RAND Corporation, Santa Monica, CA

Parrado EA, Cerrutti M (2003) Labor migration between developing countries: the case of Paraguay and Argentina. Int Migrat Rev 37(1):101-132

Paul SK (2014) Determinants of evacuation response to cyclone warning in coastal areas of Bangladesh: a comparative study. Oriental Geographer 55(1-2):57-84

Price GN (2008) Hurricane Katrina: was there a political economy of death? Rev Black Political Econ 35(4): $163-180$

Ramadan A (2013) Spatialising the refugee camp. Trans Inst Br Geogr 38(1):65-77

Redlener IM (2006) Americans at Risk: why we are not prepared for Megadisasters and what we can do now. Knopf, New York, NY 
Reed RK (2015) Environmental destruction, guaraní refugees, and indigenous identity in Urban Paraguay. In: Wood DC (ed) Climate change, culture, and economics: anthropological investigations. Emerald Group Publishing Limited, Bingley, UK, pp 263-292

Renaud F, Bogardi J, Dun O, Warner K (2007) Control, adapt or flee how to face environmental migration? Interdisciplinary Security Connections Publication Series of UNU-EHS 5

Riad JK, Norris FH, Ruback RB (1999) Predicting evacuation in two major disasters: risk perception, social influence, and access to resources. J Appl Soc Psychol 29(5):918-934

Romero M (2006) Racial profiling and immigration law enforcement: rounding up of usual suspects in the Latino community. Critical Sociol 32(2-3):447-473

Rotter R (2016) Waiting in the Asylum determination process: just an empty interlude? Time Soc 25(1):80-101

Schaap A (2011) Enacting the right to have rights: Jacques Ranciére's critique of Hannah Arendt. Eur J Polit Theor 10(1):22-45

Settlage RD (2009) Affirmatively denied: the detrimental effects of a reduced grant rate for affirmative asylum seekers. Boston Univ Int Law J 27(61):61-113

Shacknove AE (1985) Who is a refugee? Ethics 95(2):274-284

Silverman SJ (2008) Redrawing the lines of control: political interventions by refugees and the sovereign state system. Dead/Lines: Contemporary Issues in Legal and Politics Theory 1-27

Stratford E, Farbotko C, Lazrus H (2013) Tuvalu, sovereignty and climate change: considering Fenua, the archipelago and emigration. Island Stud J 8(1):67-83

Tabucanon G (2012) The Banaban resettlement: implications for Pacific environmental migration. Pacific Stud 35(3):343-370

Tabucanon G, Opeskin B (2011) The resettlement of Nauruans in Australia: an early case of failed environmental migration. J Pacific History 46(3):337-356

Thielemann ER (2004) Why Asylum policy harmonisation undermines refugee Burden-sharing. Eur J Migr Law 6:47-65

The Weather Channel (2017) September 2017 Was the Most Active Month on Record for Atlantic Hurricanes. https://weather.com/storms/hurricane/news/september-2017-most-active-month-onrecord for-atlantic-hurricanes

Tiefenbacher JP, Wilson SN (2012) The barriers impeding precautionary behaviours by undocumented immigrants in emergencies: the hurricane Ike experience in Houston, Texas, USA. Environ Hazards 11(3): 194-212

Tukur S (2017) 100,000 Killed, two million displaced by Boko Haram insurgency, Borno Governor Says. Premium Times, 13 February

Unicef UK (2017) No place to call home: protecting children's rights when the changing climate forces them to flee. London: Unicef. https://downloads.unicef.org.uk/wp-content/uploads/2017/ 04/No-Place-To-Call-Home.pdf?_ga=2.73316244.623674493.1494945170-1964912592.14836 24860

United Nations (UN) (1951) 1951 Convention Relating to the Status of Refugees. Geneva

United Nations (UN) (1990) International Convention on the Protection of the Rights of All Migrant Workers and Members of their Families

United Nations (UN) (1998) OCHA Guiding Principles on Internal Displacement. New York and Geneva

United Nations Framework Convention on Climate Change (UNFCCC) (2017) Task force on displacement at a glance. The Warsaw International Mechanism for Loss and Damage, United Nations

United Nations Population Division (2017) Trends in International migrant stock: The 2017 revision. Department of Economic and Social Affairs. (United Nations database, POP/DB/MIG/Stock/Rev.2017)

Van Willigen M, Edwards M, Edwards B, Hesse S (2002) Riding out the storm: experiences of the physically disabled during Hurricanes Bonnie, Dennis, and Floyd. Natural Hazards Review 3(3):98-106 
Vecchi GA, Soden BJ (2007) Global warming and the weakening of the tropical circulation. J Clim 20(17):4316-4340

Vieira RMSP, Tomasella J, Alvalá RCS, Sestini MF, Affonso AG, Rodriguez DA, Barbosa AA, Cunha APMA, Valles GF, Crepani E, de Oliveira SBP, de Souza MSB, Calil PM, de Carvalho MA, Valeriano DM, Campello FCB, Santana MO (2015) Identifying areas susceptible to desertification in the Brazilian Northeast. Solid Earth 6(1):347-360

Voigt-Graf C, Kagan S (2017) Migration and labour mobility from Kiribati. development policy centre discussion Paper No. 56. Available at SSRN: https://ssrn.com/abstract=2937416 or http:// dx.doi.org/10.2139/ssrn.2937416

Walker A (2012) What is Boko Haram?. US Institute of Peace, Washington, DC

Ward ME, Shelley K, Kaase K, Pane JF (2008) Hurricane Katrina: A longitudinal study of the achievement and behavior of displaced students. J Educ Stud Placed at Risk 13(2-3):297-317

Warner K, Hamza M, Oliver-Smith A, Renaud F, Julca A (2010) Climate change, environmental degradation and migration. Nat Hazards 55:689-715

World Bank (2015) South Asia Population, Urban Growth: A Challenge and an Opportunity. Available at: http://go.worldbank.org/K67SR8GMQ0

Open Access This chapter is licensed under the terms of the Creative Commons Attribution 4.0 International License (http://creativecommons.org/licenses/by/4.0/), which permits use, sharing, adaptation, distribution and reproduction in any medium or format, as long as you give appropriate credit to the original author(s) and the source, provide a link to the Creative Commons license and indicate if changes were made.

The images or other third party material in this chapter are included in the chapter's Creative Commons license, unless indicated otherwise in a credit line to the material. If material is not included in the chapter's Creative Commons license and your intended use is not permitted by statutory regulation or exceeds the permitted use, you will need to obtain permission directly from the copyright holder. 